\title{
Election Interference: The Real Harm and The Only Solution
}

\author{
Jens David Ohlin*
}

\begin{abstract}
Although politicians and intelligence analysts have criticized Russian interference in the 2016 and 2018 elections, international lawyers seem to be at a loss for how to understand the particular harm posed by this interference. In addition to the hacking of email accounts and disclosure of private information, the most salient aspect of the interference was the use of social media platforms, including Twitter and Facebook, to sow division and heighten nativist tendencies within the electorate. Strictly speaking, the goal of the 2016 interference was to delegitimize a potential Clinton presidency or to help elect Donald Trump as president. But far more important was the method used to accomplish these goals: the impersonation of American citizens during participation in the political process. This latter development points to the real harm of election interference, which has less to do with sovereignty and more to do with the collective right of selfdetermination. Foreign interference is a violation of the membership rules for political decision-making, i.e., the idea that only members of a polity should participate in elections - not only with regard to voting but also with regard to financial contributions and other forms of electoral participation. Outsiders are free to express their opinions but covertly representing themselves as insiders constitutes a violation of these political norms, which are constitutive of the notion of selfdetermination, just as much as covertly funneling foreign money to one candidate. The only solution to this form of election interference is transparency, i.e., to expose such interventions for what they are: attempts by foreigners to make political statements while pretending to be Americans. This article ends by cataloguing the mistakes of the Obama Administration in failing to expose this interference in real time - which is the only way to nullify its insidious impact. Ex post investigations, prosecutions, and counter-measures designed to deter future misbehavior are all insufficient to nullify the impact of electoral interference. However, recent efforts by the Justice Department and the FBI, including a new policy codified in the US Attorneys Manual, and contemporaneous indictments of Russians for interference in the 2018 election, suggest that some government actors finally understand that transparency is the only solution to election interference.
\end{abstract}

\footnotetext{
*Vice Dean and Professor of Law, Cornell Law School.
} 


\section{INTRODUCTION}

In the immediate aftermath of the 2016 election, the Office of the Director of National Intelligence (ODNI) released a report that concluded that the Russian government interfered in the 2016 presidential election. ${ }^{1}$ The report was notable for many reasons, though perhaps not for the same reason that gained so much public attention. At the time, journalists were focused on the fact that the conclusion of the ODNI was that Russia interfered in the election, even though President Trump distanced himself from this conclusion and refused to endorse the empirical findings of his own intelligence analysts. ${ }^{2}$ But equally surprising was the fact that the intelligence community was disclosing the interference - and detailing its scope-after the election, when nothing could be done to counteract the interference. During the period in time when the interference occurred, the intelligence community, and law enforcement agencies with jurisdiction over counter-intelligence, said precious little about the interference.

International lawyers have had their own reaction to the election interference. Some have tried to place the Russian influence campaign in historical context, noting that the United States has engaged in its own share of electoral interference or propaganda efforts in other countries. ${ }^{3}$ Other lawyers have argued that the First Amendment, or some broader principle of freedom of speech, protects the rights of anyone who wants to meddle in an election, even a foreign one. ${ }^{4}$ Other

${ }^{1}$ Office of the Director of National Intelligence, Assessing Russian Activities and Intentions in Recent US Elections (January 6, 2017) (concluding that "[w]e assess Russian President Vladimir Putin ordered an influence campaign in 2016 aimed at the US presidential election. Russia's goals were to undermine public faith in the US democratic process, denigrate Secretary Clinton, and harm her electability and potential presidency. We further assess Putin and the Russian Government developed a clear preference for President-elect Trump.”).

2 Trump first made the following ambiguous statement: "I accept our intelligence community's conclusion that Russia's meddling in the 2016 election took place. It could be other people also. There's a lot of people out there." He also said: "They said they think it's Russia; I have President Putin, he just said it's not Russia. I will say this: I don’t see any reason why it would be.” Trump later articulated that he believed that Russia intervened in the election. See Mark Landler and Maggie Haberman, A Besieged Trump Says He Misspoke on Russian Election Meddling, New York Times (July 17, 2018).

3 See Michael N. Schmitt, "Virtual" Disenfranchisement: Cyber Election Meddling in the Grey Zones of International Law, 19 Chi. J. Int'l L. 30, 32 (2018) ("Indeed, the U.S. has a long history of involving itself covertly and overtly in foreign elections.").

${ }^{4}$ See Joseph Thai, The Right to Receive Foreign Speech, 71 Okla. L. Rev. 269, 278 (2018) (dismissing the ideas that foreigners outside of the U.S. have a constitutional right to free speech but exploring whether Americans have a first amendment right to "receive" foreign speech). See also Nathaniel A. G. Zelinsky, Foreign Cyber Attacks and the American Press: Why the Media Must Stop Reprinting Hacked Material, 127 Yale L.J. Forum 286, 293 (2017). 
international lawyers have focused on the cyber-intrusions, including the hacking of the DNA email server, as evidence that Russia either directly engaged in a cyberattack against the United States or was complicit in cyber-attacks committed by Wikileaks or associated individuals. ${ }^{5}$ This has raised difficult questions about whether such cyber-attacks violate the nascent norms regarding cyber law, which most recently was the subject of Tallinn Manual 2.0, an effort to articulate the customary international law rules governing cyberspace. ${ }^{6}$

Common to all of this discourse is an assumption that the concept of "sovereignty" is the best rubric for understanding and debating election interference. This essay is meant as a small corrective to reorient the debate around an alternative concept, the idea of self-determination - i.e., the idea that peoples have a right to select their own political destiny, a process that in democratic societies is actualized through the electoral process. I argue in this essay that understood in this way, self-determination entails that a people have a right to enforce membership rules for elections and create a process that privileges insiders over outsiders. Part I of the essay briefly describes and analyzes Russia's interference in the 2016 and 2018 elections. Part II focuses on the existing legal debate over election interference and why the existing literature has failed to capture its distinctive harm. Then, Part III outlines its distinctive harm as a violation of the membership rules for the election process, especially when outsiders masquerade as insiders in order to influence the election. Finally, Part IV evaluates the potential governmental responses to election interference-including retorsions, covert counter-measures, and criminal indictments - and concludes that governments must ensure transparency in the political process by exposing covert election interference in real time before the election is over. Part $\mathrm{V}$ address objections to this account.

\section{WHAT IS ELECTION INTERFERENCE?}

Prior to the 2016 presidential election, Russian intelligence services launched a major campaign to disrupt and influence the US election. The interference was inspired by multiple goals: to sow discord and confusion in the US political system; to encourage Americans to fight against each other along partisan divides in lieu of fighting against a common external enemy; to delegitimize Hillary Glinton if she won the presidential election; and to help elect Donald Trump as

\footnotetext{
${ }^{5}$ See generally Andrew Moshirnia, No Security Through Obscurity Changing Circumvention Law to Protect Our Democracy Against Cyberattacks, 83 Brook. L. Rev. 1279, 1279 (2018).

6 Tallinn Manual 2.0 on the International Law Applicable to Cyber Operations (Michael N. Schmitt ed., 2d ed. 2017)
} 
president. ${ }^{7}$ To accomplish these goals, the Russian interference program included voter suppression efforts, election boycotts to reduce turnout, and support for thirdparty candidates (such as the Green Party's Jill Stein) who would draw support away from main-party candidates, especially Hillary Clinton. ${ }^{8}$

One possible motivation for preferring Trump over Clinton, or for delegitimizing a possible Clinton presidency, was an assumption on Russia's part that Clinton would imposed an explicit or implicit policy goal of regime change in Russia, on account of corruption and human rights abuses by President Putin. Consequently, Putin may have viewed a Clinton presidency as an existential threat and decided to launch a form of information warfare as a campaign of political selfdefense. While it is unlikely that Clinton would have actually pursued regime change as official American foreign policy, there was sufficient tension between the two individuals during Clinton's time running the State Department that Putin likely believed that Clinton was a major threat, regardless of whether that was true or not. At the start of Russia's influence operation, the goal was probably more to delegitimize Clinton and sow confusion, but as the election entered its Eleventh hour, and Clinton's lead in the polls evaporated, the goal of electing Donald Trump could have played a supporting motivation for the election interference.

There were several methods used during the election interference. Chief among them was the hacking of emails belonging to John Podesta and DNC officials, and the dissemination of those emails through Wikileaks and other outlets. ${ }^{9}$ Trump himself famously solicited Russia to "find" Clinton's emails during a speech in Florida. ${ }^{10}$ In addition to the hacking of email accounts, Russian intelligence services operated a troll farm that created fake Twitter and Facebook accounts. Some of these accounts involved the creation of fictitious advocacy groups, whereas other accounts simply spread inflammatory political statements. Falling within the latter camp were accounts that merely amplified other statements by either

7 Assessing Russian Activities and Intentions in Recent US Elections, supra note 1, at ii (concluding that "Moscow's approach evolved over the course of the campaign based on Russia's understanding of the electoral prospects of the two main candidates. When it appeared to Moscow that Secretary Clinton was likely to win the election, the Russian influence campaign began to focus more on undermining her future presidency.").

${ }^{8}$ For more on these efforts, see Young Mie Kim, Uncover: Strategies and Tactics of Russian Interference in US Elections (September 4, 2018).

${ }^{9}$ Podesta was a former White House Chief of Staff and was Campaign Chairman of the Hillary Clinton presidential campaign.

10 See Ashley Parker and David E. Sanger, Donald Trump Calls on Russia to Find Hillary Clinton's Missing Emails, New York Times (July 27, 2016) (quoting Trump stating in televised speech that "Russia, if you're listening, I hope you're able to find the 30,000 emails that are missing... I think you will probably be rewarded mightily by our press."). 
retweeting or resharing other posts, or accounts that generated their own inflammatory statements. Some of this activity was automated and the product of "bot" accounts, while others were individually created by human operators working at the troll farms. ${ }^{11}$

The scope of the influencing campaign was not originally well understood. In the early days after the 2016 election, when Twitter and Facebook were slow to investigate the nature of this influence campaign, Twitter initially indicated that there were roughly 200 fake Russian Twitter accounts responsible for spreading a few thousand tweets. ${ }^{12}$ Over time that number has grown substantially. In October 2018, Twitter announced that fake Russian accounts were responsible for more than 9 million tweets. ${ }^{13}$

One important factor in the Russian accounts was that the posters often pretended, either explicitly or implicitly, to be American when posting about American politics. Through the strategic use of profile photographs, profile descriptions, ${ }^{14}$ and previously posted content, the accounts were designed to appear as if they were created and maintained by American citizens participating in the political process. ${ }^{15}$ Borrowing a term from the lobbying arena, one might refer to this as "AstroTurf electioneering." 16

11 See Neil MacFarquhar, Inside the Russian Troll Factory: Zombies and a Breakneck Pace, New York Times (Feb. 18, 2018) (discussing the use of bots and other automated techniques in Russia social media campaigns).

12 See Jessica Guynn and Erin Kelly, Twitter removed 200 Russian accounts that targeted Facebook users during election, USA Today (Sept. 28, 2017).

${ }^{13}$ See Aja Romano, Twitter released 9 million tweets from one Russian troll farm. Here's what we learned: The massive data dump reveals how trolls disrupt and destabilize local and global politics, Vox (Oct 19, 2018) ("The size of this release, however, confirms much of what experts have long suspected about the scope and function of the tweets - and further establishes that the goals of these propaganda farms, which mainly hail from Russia and Iran, involve not only the disruption of US politics but also the distortion of political debate in their own backyards."). Many of the 9 million tweets were in Russian language and were designed to influence domestic political issues in Russia, such as the civil war in Eastern Ukraine.

14 See Savvas Zannettou \& Jeremy Blackburn, How to tell a Russian troll from a regular person, Houston Chronicle (Sep. 5, 2018).

15 See Scott Shane, The Fake Americans Russia Created to Influence the Election, New York Times (Sept. 7, 2017) (describing the social media posts of Melvin Redick of Harrisburg, Pa., "a friendly-looking American with a backward baseball cap and a young daughter" but noting that "Mr. Redick turned out to be a remarkably elusive character. No Melvin Redick appears in Pennsylvania records... [but] this fictional concoction has earned a small spot in history: The Redick posts that morning were among the first public signs of an unprecedented foreign intervention in American democracy.").

16 The term AstroTurf lobbying refers to an advocacy group that pretends to be a grass-roots initiative but is, in fact, created by a corporate group with an interest in influencing governmental 
It is precisely these covert social media influencing campaigns that I wish to focus on. For the moment, I wish to keep the crime of computer hacking, and the release of DNC emails, to the side. Email hacking is a domestic crime under federal law and also raises important issues under both international law and strategy, but the use of social media influencers in the political process was the hallmark of Russia's troll farm activity during the 2016 election. The goal of this essay is to conceptualize the harm of these efforts and outline what remedy, if any, is politically, ethically, and legally appropriate under the circumstances.

\section{THE LEGAL FRAMEWORK FOR EVALUATING INTERFERENGE}

According to most international lawyers, the basic rubric for evaluating legal election interference involves a resort to the basic standards for non-intervention. ${ }^{17}$ In the context of military force, the rules regarding intervention are relatively easy to apply; military intervention is never permitted, according to article 2 of the UN Charter, unless one of two exceptions applies (self-defense or a security council authorization). In contrast, the rules regarding non-military interventions are far more difficult to articulate and even harder to apply. According to the Tallinn Manual, a non-military intervention will violate the sovereignty of a state if the intervention involves either coercion or a usurpation of an inherently governmental conduct. ${ }^{18}$ This articulation of the rule might sound strangely permissive in that it allows interventions in many situations that do not fall under these two exceptions (coercion and usurpation). It should be recalled, though, that state actors engage in activities every day that impact foreign states in some manner - activities that one might describe as economic, diplomatic, commercial, social, or cultural behaviors. Any one of them could, in theory, be described with the language of sovereignty, i.e., one could use the language of sovereignty to say that the behavior in question is an illegal violation of a state's sovereignty. So, the goal of legal doctrine must be to distinguish between permissible infringements of sovereignty and those which cross a line of legal significance.

It was with this task in mind that the Tallinn Manual, drawing on norms articulated in the ICJ's Nicaragua decision, noted that a state's sovereignty would be

regulation. The point of the term is that the advocacy styles itself as something - a grass-roots effort - that it is not. Consequently, the term "grass-roots electioneering" could refer to a coordinated effort to produce fraudulent social media content that appears to be organically generated at the grass-roots level.

17 See Schmitt, supra note 3, at 50; Brian J. Egan, Legal Adviser, U.S. Dep't of State, International Law and Stability in Cyberspace, Speech at Berkeley Law School on (Nov. 10, 2016) (arguing that an attack against election infrastructure would be an illegal infringement of American sovereignty).

18 See Tallinn Manual 2.0, supra note 6, at 23. 
violated by an action that involves coercion or usurps an inherently governmental function. ${ }^{19}$ Neither legal standard fits the facts of election interference with any degree of clarity. ${ }^{20}$ Take coercion first. The Russian interference in the 2016 election involved a desire to achieve a particular result - the delegitimization of Hillary Clinton or the election of Donald Trump - but not through the mechanism of coercion per se. ${ }^{21}$ The mechanism involved impersonation of U.S. citizens through social media to amplify particular social and political positions, thereby increasing partisan rancor and the type of political anger that encourages people to vote. The key mechanism here was deception, not coercion. It was not as if the Russians forced people to vote for Donald Trump otherwise certain unpleasant consequences would follow (such as economic punishments, or the like). ${ }^{22}$

As for the second standard, usurpation, the election interference might have met the standard if it had involved direct manipulation of vote tallies, manipulation of voter registration rolls, manipulation of the internal code of electronic vote machines, false information about when or where voting stations would be open, or any other behavior that would have compromised the bureaucratic process of holding the election or counting the votes. ${ }^{23}$ Almost every international law would concede that this type of interference would be an illegal infringement against a state's sovereignty because it involves a usurpation of an inherently governmental activity. ${ }^{24}$

The problem is that neither of these standards provides a good description of Russian interference in the 2016 or 2018 elections. While it remains to be seen whether more direct forms of interference might happen in the future, this essay

${ }^{19}$ Military and Paramilitary Activities in and Against Nicaragua (Nicaragua v. United States), Judgment, 1986 I.C.J. Rep. 14, \ 205 (June 27) (concluding that coercion "defines, and indeed forms the very essence of, prohibited intervention").

${ }^{20}$ Many of these standards are discussed in Oona A. Hathaway et al., The Law of Cyber-Attack, 100 Calif. L.R. 817 (2012); Patrick Franzese, Sovereignty in Cyberspace; Can it Exist., 64 Air Force L.R. 1 (2009).

21 This issue is also discussed in Jens David Ohlin, Did Russian Cyber Interference in the 2016 Election Violate International Law?, 95 Tex. L. Rev. 1579, 1592 (2017) (concluding that "there are substantial impediments to concluding that the Russian hacking in the 2016 election constituted illegal coercion").

${ }^{22} I d$.

23 Schmitt, supra note 3, at 45-46.

${ }^{24}$ See Tallinn Manual 2.0, supra note 6, at 22 (giving the following examples: "changing or deleting data such that it interferes with the delivery of social services, the conduct of elections, the collection of taxes, the effective conduct of diplomacy, and the performance of key national defense activities"). 
focuses on the information warfare that Russia and other states are using on social media platforms, which does not primarily involve coercion or usurpation.

I have argued elsewhere that this social media information warfare is illegal, not because it constitutes an illegal intervention against a state's sovereignty, but rather because it constitutes a violation of a people's collective right of selfdetermination. ${ }^{25}$ Although self-determination is largely recognized as a central human right, codified and protected in article 1 of the ICCPR, most international lawyers are inclined to deemphasize self-determination as a right. ${ }^{26}$ There are many reasons for this delegitimization process; one reason might be that the right is collective, rather than individual, and therefore falls outside the basic paradigm of individual rights based on human dignity that are protected under the human rights movement. ${ }^{27}$ Another reason is that self-determination is attributed to peoples, not states, and international lawyers have a difficult time wrapping their minds around a right that is attributed neither to states nor individual human beings, but instead a collective entity whose boundaries are defined not by positive law but by human relationships. The prevailing attitude of legal positivism, and the focuses on positive sources of law, is problematic because one cannot look to the positive sources of law to find a definition of which entities count as peoples or not. That determination must be made by reference to extra-legal categories. ${ }^{28}$

The concept of self-determination has usually been employed to entail a right of secession in situations where a people's self-determination is not actualized within their current political arrangement. ${ }^{29}$ But the right of self-determination is so much more and runs so much deeper. It includes the right of a people to select their own political destiny, or as the ICCPR puts it, "[b]y virtue of that right they freely determine their political status and freely pursue their economic, social and cultural development." 30 In a democratic polity, the engine of that process is the

25 Ohlin, supra note 21, at 1580-81.

26 International Covenant on Civil and Political Rights (ICCPR), art. 1, Dec. 19, 1966, 999 U.N.T.S. 171 ("All peoples have the right of self-determination. By virtue of that right they freely determine their political status and freely pursue their economic, social and cultural development.").

27 See generally, Antonio Cassese, Self-Determination of Peoples: A Legal Reappraisal (1995). See also Gregory H. Fox, Self-Determination in the Post-Cold War Era: A New Internal Focus? 16 Mich. J. Int'l L. 733 (1995) ("with the effective end of decolonization and the virtually unanimous refusal of states to recognize a right of secession, the legal norm appears to have been deprived of much of its content").

${ }^{28}$ For more discussion on this point, see Jens David Ohlin, The Right to Exist and the Right to Resist, in The Theory of Self-Determination 70 (F. Teson ed., 2016).

29 This was, for example, the conclusion of the Canadian Supreme Court advisory opinion on the question of Quebec's secession.

30 ICCPR, supra note 26. 
work of representative government whose officials make decisions, about matters small and large, on behalf of the people that they represent. That process of representative government does not happen by divine right of kings - it happens because the people select their own governing representatives through a process of election. ${ }^{31}$ And elections happen in a specific way, not just by engaging in a popularity contest, as in a high school election for student council, but a public debate about the normative choices required by governing. The people, in other words, vote for and select the representatives who will work to implement a political vision that the voters wish to endorse. ${ }^{32}$ In a democratic society, this is the meaning of self-determination and it is inextricably linked to the electoral process.

In the following section, I seek to evaluate modern electoral interference in relation to this political conception of self-determination. ${ }^{33}$ In particular, I hope to respond to various objections that election interference involves nothing more troubling than exercising the right to free speech or the right to participate in the political process. If Americans can express political viewpoints on Twitter, why should not the Russians? More specifically, what is wrong with a troll farm in Russia employing a large group of individuals to post statements and opinions on Twitter and Facebook? Why would this behavior compromise the collective right of selfdetermination? Answering this question requires a more complete picture not just of self-determination, but also about defining the outer boundaries of a political community, i.e., who is a member of the polity. Only once we have a complete account of political membership - of who is an insider and who is an outsider, and who gets to define these terms - can we understand the role that elections play in the right of self-determination under international law.

\footnotetext{
${ }^{31}$ See, e.g., John W. Head, Selling Hong Kong to China: What Happened to the Right of Self-Determination?, 46 U. Kan. L. Rev. 283, 291 (1998) (concluding that "the sources of law on the right of selfdetermination are fairly clear on this point. In referring to the means by which the right of selfdetermination is to be achieved, the sources consistently use such language as 'freely expressed will and desire,' 'political status freely determined by a people,' and 'free and voluntary choice... expressed through informed and democratic processes."').

32 See Principles Which Should Guide Members in Determining Whether or Not an Obligation Exists to Transmit the Information Called for Under Article 73e of the Charter, G.A. Res. 1541, U.N. GAOR, 15th Sess., Annex 29, U.N. Doc. A/4684 (1960).

${ }^{33}$ For a discussion, see Duncan Hollis, The Influence of War; the War for Influence, 32 Temp. Int'l \& Comp. L.J. 31, 43 (2018) ("applying the right to self-determination in the IO context presupposes a capacity to identify with sufficient specificity the impact of an IO like "fake news" on a voting public").
} 


\section{THE REAL HARM}

The following section will connect the harm of election interference with a core conception of self-determination. The goal is to explain, in both political and legal terms, the distinctive harm imposed by election interference, and why it would count as a violation of the collective right of self-determination.

To answer this question, it is important to consider a key skeptical challenge that one often hears from international lawyers: i.e., that all individuals enjoy freedom of speech, both under U.S. and international law, and that political speech of any kind is protected by the U.S. Constitution and the relevant international protocols. ${ }^{34}$ This has led some to suggest that Russian social media trolls have just as much right to post inflammatory views on Twitter and Facebook as an individual living in California, Texas, or New York. While freedom of speech is undeniably protected by these sources of law, it is not an absolute right and it is subject to regulation. In the context of electoral politics, speech (including campaign financing) is regulated according to the background rules and principles governing participation in the political process.

We saw above that elections fulfill the right of a people to select their own political destiny. In order to accomplish this goal, a political system will establish criteria for who can participate in the political process. For example, only citizens can vote in an election in the United States and in most democratic political systems. ${ }^{35}$ Non-citizens are excluded from this form of political participation. Why would this discrimination be permitted, given that the government creates and enforces laws against non-citizens residents? While residents are subject to the government's coercive authority, residents have no authority to participate in the process of selecting the government. ${ }^{36}$ The only answer is that citizens are permanent members of the polity and as such as allowed to participate in the process of selecting the polity's future direction. ${ }^{37}$

Campaign finance regulations rely on the same distinction between members and non-members of the polity. ${ }^{38}$ Citizens are entitled to give financial

\footnotetext{
${ }^{34}$ See Thai, supra note 4.

${ }^{35}$ See, e.g., 52 U.S.C. § 10101; 52 U.S.C. § 10502 (abolishing durational residency requirement for voting as unconstitutional when applied against citizens).

${ }^{36}$ For a discussion of this issue, see generally Stanley Allen Renshon, Noncitizen Voting and American Democracy 4 (2009) (arguing that non-citizens should be allowed to vote but describing the association of citizenship and voting as settled doctrine).

${ }^{37} \mathrm{Id}$.

${ }^{38}$ See Toni M. Massaro, Foreign Nationals, Electoral Spending, and the First Amendment, 34 Harv. J. of L. \& Pub. Pol'y 663, 685 (2011).
} 
contributions to any political candidate, outside contributions from foreigners are strictly prohibited. ${ }^{39}$ Again, one might ask what justifies this categorical exclusion of foreigners from the political process. The only answer is that an election is supposed to be an expression of the polity's collective decision-making and allowing foreign contributions would turn an election into something else - an expression of the political will of the outsiders too. Outsiders usually belong to their own political entities and are entitled to participate there - but allowing universal participation in the political process would effectively undermine the existence of independent polities representing distinct peoples. ${ }^{40}$

In some situations, a polity will see fit to "suspend" membership in the polity when individuals behave particularly badly. For example, convicted felons are sometimes disenfranchised and prohibited from voting in state and federal elections. Setting aside whether such "felon disenfranchisement" statutes are advisable or not, ${ }^{41}$ it is important to understand their basic structure. ${ }^{42}$ In making this determination, the polity declares that membership in the decision-making class can be forfeited by felonious conduct. ${ }^{43}$ This legal maneuver just highlights that for purposes of political decision-making, there are insiders and outsiders. ${ }^{44}$ Elections only make sense once those distinctions are made. And chief among those distinctions is the distinction between citizens and foreigners. The underlying rationale for this distinction is that elections cease to be an expression of a polity's decision-making if outsiders are permitted to participate in them. Moreover, the criteria for insider membership status is determined by the polity itself. The polity

\footnotetext{
39 See, e.g., 52 U.S.C. $\$ 30121$ (prohibiting foreign nationals from directly or indirectly contributing to a political campaign). However, those with permanent resident status (such as green-card holders) are permitted to donate to a political campaign. Presumably the theory behind the distinction is that permanent residents sufficiently belong to the polity - by virtue of the permanency of their residency that they are permitted this form of political participation.

${ }^{40}$ But see Renshon, supra note 36.

${ }^{41}$ There is a vast literature criticizing the wisdom and racial impacts of felon disenfranchisement. For a good survey of the literature, see Developments in the Law, One Person, No Vote: The Lawes of Felon Disenfranchisement, 115 Harv. L. Rev. 1939 (2002).

${ }^{42}$ See, e.g., S. Brannon Latimer, Can Felon Disenfranchisement Survive Under Modern Conceptions of Voting Rights?: Political Philosophy, State Interests, and Scholarly Scorn, 59 SMU L. Rev. 1841, 1844 (2006).

${ }^{43}$ See Roger Clegg, George T. Conway III, Kenneth K. Lee, The Case Against Felon Voting, 2 U. St. Thomas J.L. \& Pub. Pol'y 1, 17 (2008) (noting that "felon disenfranchisement laws are justified on the basis of Locke's notion of the social contract: As Judge Henry Friendly once put it, someone 'who breaks the laws' may 'fairly have been thought to have abandoned the right to participate' in making them").

${ }^{44}$ Indeed, the case against felon disenfranchisement logically depends on the idea that felons remain members of the political community, even if they have violated its rules.
} 
determines the criteria for citizenship (jus solis or jus sanguinis) and also determines the criteria for suspending that membership in the case of egregious law-breaking (felon disenfranchisement). ${ }^{45}$

The polity also distinguishes between insiders and outsiders by crafting rules governing immigration. ${ }^{46}$ Immigration has been the source of intense political strife during the last administration, with Trump supporters arguing for restrictions on illegal and legal immigration and critics arguing for immigration reform. Underlying both positions, however, is a recognition that a polity is entitled to manage its borders in such a way that defines who may enter and potentially join the polity, first as a lawful permanent resident and eventually as a possible citizen. Immigration control is yet another example of how a polity may legitimately define, regulate, and select its own membership. ${ }^{47}$

This conception of elections as an expression of political self-determination helps explain the distinctive harm of election interference. When Russian military intelligence set up a troll farm to operate fictitious Twitter and Facebook accounts, they did so in order to make statements that would appear to come from American sources. Indeed, if the posts had transparently identified their Russian source, no one on Twitter or Facebook would have cared about the opinions that they expressed. The extreme political viewpoints posted by members of the troll farmwhether they were far right or far left viewpoints - gained traction because they were ostensibly expressions of real American citizens. In a highly partisan context, Americans debate each other and then go to the polls; the views of outsiders, while interesting, are not part of the electoral contest. In other words, the work of the Russian troll farms only worked because the operators impersonated Americans and their habits on social media, going so far as to adopt turns-of-phrase, iconography, and photographs that marked them out as Americans. ${ }^{48}$ These were not Russians articulating their views as Russians in the electoral process, but Russians impersonating Americans and then articulating viewpoints whose political currency depended on the fiction that they were Americans.

45 See Fox, supra note 27, at 760-61; Joseph W. Dellapenna, Constitutional Citizenship Under Attack, 61 Vill. L. Rev. 477, 490 (2016).

46 See Peter H. Schuck \& Rogers M. Smith, Citizenship Without Consent: Illegal Aliens in the American Polity (1985).

47 See, e.g., Ayelet Shachar, The Race for Talent: Highly Skilled Migrants and Competitive Immigration Regimes, 81 N.Y.U. L. Rev. 148, 155 (2006) ("Indeed, countries are willing to go so far as to reconfigure the boundaries of political membership in order to gain the net positive effects associated with skilled migration.").

48 See supra note 13. 
These facts point the way to the distinctive harm of this type of election interference. By posing as Americans, the Russian troll farms sought to gain inside access to the political process and to distort the political discourse, not by injecting points of view that were not already there, but rather to amplify viewpoints that had laid dormant but were considered marginal and in many cases outside the political mainstream. By amplifying those viewpoints, the political discourse was fundamentally altered and most importantly, it was altered by individuals who were not members of the polity.

At this point one might object that there is no firm evidence that the election interference changed the outcome of the election. ${ }^{49}$ This suggests an important clarification. First, it is unclear whether the outcome of the election was changed or not. The lack of any firm of evidence that the outcome of the election was altered by troll farm activity simply boils down to the fact that the assertion that the election result was altered is a counter-factual statement that would be extremely hard, or impossible, to support with empirical evidence. But absence of evidence is not evidence of absence. The more credible conclusion is that it is very hard to predict how the election might have unfolded in the absence of the interference. This leaves us in a state of ignorance rather than a state of certainty that the interference was not outcome-determinative.

More importantly, however, there is another response to this objection. The argument presented in this essay does not depend on the assertion that the election interference changed the outcome of the election. The particular harm flowed from the fact that the Russians participated in the electoral process while pretending to be Americans. This had a distortionary impact on the electoral process, which is problematic because an election is supposed to articulate the view of the polity, i.e., a fulfillment of that polity's right of self-determination. Once outsiders insert themselves into that process, while pretending to be insiders, the election becomes a function of other-determination rather than self-determination. The election expresses the political will of outside entities rather than the entity that is holding the election.

This political account of elections as an articulation of a polity's selfdetermination helps explain why the covert nature of the election interference was crucial to its illegality as a violation of the principle of self-determination. As already explained above, the individual account holders in the troll farm did not publicly disclose their status as Russians. However, in addition to this deception, Russia

49 See Assessing Russian Activities and Intentions in Recent US Elections, supra note 1, at i (clarifying that "[w]e did not make an assessment of the impact that Russian activities had on the outcome of the 2016 election. The US Intelligence Community is charged with monitoring and assessing the intentions, capabilities, and actions of foreign actors; it does not analyze US political processes or US public opinion."). 
itself, at the state level, refused to acknowledge the existence of the troll farm or its connection to Russian military intelligence or its connection to official state policy. ${ }^{50}$ The interference remained covert and unacknowledged at both the individual and collective levels. If, on the other hand, the Russians had admitted that they were participating in the American electoral process, that participation would not have been problematic because it would have been clear that the opinions expressed by the troll farm were an expression of the sovereign will of the Russian government or the Russian people. At that point, the problematic nature of the interference would have completely evaporated. But of course, if the Russians had acknowledged the effort, it would have lost its effectiveness as well, because as discussed above, the logic behind the effort required that the Russians participate in the political process under the guise of membership in the American polity.

I should note that some scholars and political commentators have suggested that election interference is a violation of U.S. "popular sovereignty." 51 These invocations of "sovereignty" get at the right idea and should be viewed as quite distinct from how public international lawyers use the word "sovereignty." "In political theory and political science, the notion of "popular sovereignty" refers to the exercise of the political will of the nation or people, an idea that has much more in common with self-determination than it does with the technical definition of sovereignty used by lawyers. Part of the problem is a translation exercise: the concepts used by lawyers, political theorists, and politicians do not always line up exactly. This should come as no surprise given that "sovereignty" is something of a cluster concept housing many different ideas within its rich but often confusing rubric. But we should be absolutely clear that in the context of election interference, invocations of popular sovereignty are on the right track and should not be lumped in with my general criticism of the legal literature's sovereignty-based discourse.

\footnotetext{
50 President Trump made the following statement regarding his meeting with President Putin of Russia: "He said he didn't meddle. I asked him again. You can only ask so many times. Every time he sees me, he says, 'I didn't do that.' And I believe, I really believe, that when he tells me that, he means it."

51 See, e.g., Claire Finkelstein, How Democracy, in the Kremlin's Crosshairs, Can Fight Back, Zocalo Public Square (May 11, 2017) (concluding that "[i]nstitutions that are dependent on the concept of popular sovereignty are sitting ducks for foreign intervention carried out by cyberattack, cyber influence, and cyber manipulation.").

52 See also Ciara Torres-Spelliscy, Dark Money as a Political Sovereignty Problem, 28 Kings L.J. 239 (2017) (arguing that "[a] key factor to both sovereignty of the nation and the popular sovereignty of the American people is the soundness of the electoral process," noting that a "close corollary to sovereignty is the right of a people to self-determination," and concluding that "the concepts of sovereignty and self-determination are intertwined in a democracy, as the people in a given country decide their fate").
} 
In conclusion, the real harm of election interference flows from outsiders participating in the political process of another polity but pretending to do so as insiders. An election is supposed to be an expression of that polity's collective will, as a fulfillment of their collective right of self-determination, and outside interference has a distortionary impact on the discourse and threatens to transform what would otherwise be an expression of the polity's will with an expression of some other polity's will. ${ }^{53}$ The covert nature of the election interference is an integral part of its harm, because what is destructive about the interference is the participation of outside forces masquerading as inside members of the polity.

\section{The ONLY SOLUTION}

Now comes the hard part. What solutions are available in law and policy to counteract this form of election interference? This section will defend the proposition that there really is only one solution: transparency. Given the distinctive harm outlined in the prior section, the only solution is for the source of the interference to be exposed as foreign. Most importantly, the remedy must occur in real time, because any ex post solution will come too late to rectify the harm done to the collective right of self-determination. Once the outsiders have participated in the electoral process and the election is held, no remedies after the fact will be sufficient to vindicate the collective right of self-determination.

If I am correct about the real harm in election interference, the solution is easier than many might have thought. Since the harm flows from outsiders pretending to be insiders, it is not necessary for the election interference - the posting of opinions on Twitter and Facebook and other social media platforms - to be completely eliminated. All that needs to happen is for the interference to be unmasked as foreign in nature. In other words, the social media campaigns need to be identified as coming from outside the polity and recognized for what they are: outsiders masquerading as insiders.

Existing statutory regimes seek to promote transparency, but these regimes are patchworks and are insufficiently enforced. To take just one example, the Foreign Agents Registration Act, passed in 1938, requires that lobbyists and other foreign agents register with the federal government in order to announce their

\footnotetext{
${ }^{53}$ Matt Vega refers to this as an "anti-distortion" rationale and uses it to justify prohibitions on campaign expenditures by foreign corporations in light of Citizens United. See Matt A. Vega, The First Amendment Lost in Translation: Preventing Foreign Influence in U.S. Elections After Citizens United v. FEC, 44 Loy. L.A. L. Rev. 951, 1012 (2011) ("Campaign spending by a foreign-controlled corporation is, by definition, a distortion of an exclusively American political process."). See also Massaro, supra note 38, at 688 (discussing the anti-distortion rationale for narrow restrictions on foreign spending).
} 
representation of a foreign sovereign. ${ }^{54}$ The Act also covers political propaganda, thus providing a hook for regulating social media content, though there are issues of extraterritoriality to consider. ${ }^{55}$ Also, failure to file a FARA registration is infrequently punished, though recent events have renewed interest in using FARA as a tool for enforcing transparency in the context of covert political influence. ${ }^{56}$ For example, in 2018, the Justice Department indicted a Russian national for violations of FARA while working with the NRA and other Second Amendment advocacy organizations.

As a matter of computer technology and social media, transparency is not easy to accomplish. Advanced computer algorithms need to be developed to flag potentially problematic social media posts, but inevitably the process requires a massive investment of human capital to oversee and flag problematic developments. At the time of the 2016 elections, tech media giants such as Google, Facebook, and Twitter were woefully unprepared for this mission. Only now, in late 2018, are Facebook and Twitter hiring and investing resources in flagging deceptive foreigngenerated content during the election cycle. ${ }^{57}$ The 2018 congressional elections will be the first opportunity to test whether these private corporate solutions will work.

In addition to private sector solutions, the government has a major role to play in identifying and then publicizing covert foreign election interference. Unfortunately, on this score, the Obama Administration performed poorly. Although well intentioned, the strategy utilized by the FBI and intelligence agencies was outmoded and inappropriate for this particular problem. ${ }^{58}$ Intelligence agents, analysts, and counter-intelligence agents are designed to uncover threats and then pass them on to government leaders in a confidential or even classified setting. Government leaders usually keep these intelligence assessments secret, for fear of tipping off foreign adversaries about remedial actions the United States might take. In the case of most security threats, this policy makes good sense. In the case of

5422 U.S.C. 11.

55 For a discussion, see, e.g., Zephyr Teachout, Extraterritorial Electioneering and the Globalization of American Elections, 27 Berkeley J. Int'l L. 162, 171 (2009).

56 See Jahad Atieh, Foreign Agents: Updating Fara to Protect American Democracy, 31 U. Pa. J. Int'l L. 1051, 1067 (2010) (the DOJ's enforcement of FARA has been abysmal).

57 See, e.g., Josh Constine, Facebook will hire 1,000 and make ads visible to fight election interference, Tech Crunch (Oct. 2, 2017).

${ }^{58}$ James Comey gave the following explanation to NPR: "Separately, it's a really good question as to whether the Obama administration should've said more about the broader Russian effort. I offered to be the voice of inoculation to the American people in August. I drafted an op-ed to say, "Hey, the Russians are coming for our election. Here's what we think they're doing. It's part of a broad pattern. ... American people be warned." The administration never took me up on that and didn't get around to making a decision about disclosing the broader Russian effort until October." 
election interference, however, this policy is not just ineffectual - it is downright harmful. It allows the election interference to continue unabated because the true source of the problematic posts remain hidden, protected yet again by the classified nature of the intelligence gathering process and the remedies advanced by the Obama Administration. ${ }^{59}$

The Obama Administration engaged in strategic behavior designed to nullify the election interference. The Administration made private overtures to the Russian government demanding that the meddling stop. ${ }^{60}$ Specifically, the Administration warned the Russians that meddling in the vote tally would be met with draconian counter-measures, but apparently said little or nothing about the social media campaign. The FBI also launched criminal investigations after the election, but an ex post remedy is no solution at all to an infringement of the collective right of self-determination. And the FBI's counter-intelligence investigation was also unhelpful because it was classified and could not be disclosed to the public in any meaningful way.

The only thing that would stop the election interference from succeeding would be to expose it for what it is. Transparency is the only solution, and it requires disclosing to the American public not only the overall effort - the fact that the Russians are intervening - but also exposing the true authorship of social media activity flowing from Russian troll farms. The Obama Administration did neither of these things, in part because the American government had never experienced a problem like this, on this scale, before, and therefore had little experience in counteracting it. But new threats require new solutions, and the solutions are not ones that intelligence agencies are accustomed to. Instead of more secrecy, we need more transparency. Intelligence agencies hate transparency. But there are other organs of the government who can take the intelligence assessments and publicize the threats in a way to maximize transparency. One organ is the Justice Department, though even the Justice Department has not historically focused on

\footnotetext{
59 See Donie O’Sullivan, Curt Devine and Drew Griffin, Obama official: We could have stopped Russian trolls, GNN (March 26, 2018).

60 Obama described his conversation in the following way: "What I was concerned about in particular was making sure [the hack of the Democratic National Convention] wasn't compounded by potential hacking that could hamper vote counting, affect the actual election process itself... So in early September when I saw president Putin in China, I felt that the most effective way to ensure that that didn't happen was to talk to him directly and tell him to cut it out and there were going to be serious consequences if he didn't. And in fact, we did not see further tampering of the election process - but the leaks... had already occurred." The problem with this statement should be obvious. By stating that tampering with election counting would be met with serious consequences, Obama implicitly left the impression that Russia's social media interference would have no serious repercussions for Putin. In retrospect, this was a grievous error.
} 
public communications. ${ }^{61}$ In theory, the federal government should assign this task to a particular agency or even create a cross-agency working group with the specific task of disclosing and publicizing foreign election interference in order to neutralize it.

One reason why the Obama Administration may have decided against publicizing the Russian election interference was that it assumed, falsely as it turns out, that Hillary Clinton would win the 2016 election, and any federal government statements about Russian involvement would appear to the public as favoritism to one candidate (Clinton) over another candidate (Trump). For that reason, the administration decided to stay quiet and work behind the scenes to correct the interference. Not only was the prediction in error, but the strategy was completely incoherent. Regardless of who is going to win or not win an election, the government has just as much obligation to disclose outsiders participating in the election process masquerading as insiders, as they have an obligation to prevent foreigners from funding a presidential or congressional campaign. And they should stop such efforts regardless of who might win the election. The response should not be governed by a prediction of whether one side might win the election anyway.

Luckily, there are signs that the Justice Department is starting to understand the role that public disclosure can play in nullifying the effect of election interference. In September 2018, the Justice Department announced a new policy on "Disclosure of Foreign Influence Operations," which was codified in the Department's Justice Manual:

Our Nation's democratic processes and institutions are strong and must remain resilient in the face of this threat. It is the policy of the Department of Justice to investigate, disrupt, and prosecute the perpetrators of illegal foreign influence activities where feasible. It is also the Department's policy to alert the victims and unwitting targets of foreign influence activities, when appropriate and consistent with the Department's policies and practices, and with our national security interests.

It may not be possible or prudent to disclose foreign influence operations in certain contexts because of investigative or operational considerations, or other constraints. In some circumstances, however, public exposure and attribution of foreign influence operations can be an important means of countering the threat and rendering those operations less effective. ${ }^{62}$

The policy then goes on to list the circumstances when such disclosure would be appropriate. The list includes some obvious and less obvious examples. For

${ }^{61}$ Comey's offer to write an op-ed article about Russia's election interference is a good example of a public communication that would have been helpful.

62 See Justice Manual § 9-90.730 - Disclosure of Foreign Influence Operations (2018). The Manual was previously referred to as the "U.S. Attorneys Manual." 
example, the policy states that disclosure may be necessary to "support arrests and charges for federal crimes arising out of foreign influence operations, such as hacking or malicious cyber activity, identity theft, and fraud." 63 This largely codified existing policy. However, the policy also says that disclosure may be appropriate to notify technology companies that "their services are used to disseminate covert foreign government propaganda or disinformation, or to provide other covert support to political organizations or groups." 64 Disclosure would also be appropriate to "relevant Congressional committees." As for members of the public at large, the policy states that:

To alert the public or other affected individuals, where the federal or national interests in doing so outweigh any countervailing considerations. For example, there may be an important federal or national interest in publicly disclosing a foreign influence operation that threatens to undermine confidence in the government or public institutions; risks inciting violence or other illegal actions; or may cause substantial harm, alarm, or confusion if left unaddressed. On the other hand, in some cases, public disclosure of a foreign influence operation may be counterproductive because it may amplify or otherwise exacerbate the foreign government's messaging, or may re-victimize the victim. ${ }^{65}$

While the statement that disclosure to the public is possible when national interests outweigh countervailing considerations, the policy includes no specific indication that disclosure of a foreign influence operation should be made to counter the harmful effects of election interference. I would argue that the policy should be updated to explicitly include a preference for, or presumption in favor of, disclosing information about foreign influence operations that involve election interference of the type discussed in this essay. Given the failure of both the Obama Administration and the Justice Department to give timely notification to the public during the 2016 election, the presumption should be stated explicitly so that future administrations do not make the same mistake.

At the same time as it introduced the policy, the Justice Department's Cyber Digital Task Force released a report which included two important statements regarding remediation efforts for election meddling. First, the report stated that:

The FBI and IC partners may be able to identify and track foreign agents as they establish their infrastructure and mature their online presence, in which case authorities can work with social media companies to illuminate and ultimately
${ }^{63} I d$.
${ }^{64} I d$.
${ }^{65} I d$. 
disrupt those agents' activities, including through voluntary removal of accounts that violate a company's terms of service. ${ }^{66}$

Of course, this involves taking down the posts or suspending the accounts. In some situations that might not be possible or even advisable. What about informing the population regarding the foreign intelligence meddling? On this point, the task force report states the following:

in some circumstances, public exposure and attribution of foreign influence operations, and of foreign governments' goals and methods in conducting them, can be an important means of countering the threat and rendering those operations less effective. Of course, partisan politics must play no role in the decision whether to disclose the existence of a foreign influence operation, and such disclosures must not be made for the purpose of conferring any advantage or disadvantage on any political or social group. In addition, the Department must seek to protect intelligence sources and methods and operational equities, and attribution itself may present challenges. ${ }^{67}$

While this paragraph nods in the direction of transparency, it certainly fails to announce an unambiguous policy in favor of announcing foreign influence operations that concern elections. Given the intensity of these influence operations and the way they can impinge the polity's collective right of self-determination, the Justice Department should have articulated that the federal government has an affirmative obligation to publicly disclose election interference in real time in order to counter the negative effects of the influence operation. This was a missed opportunity for both the cyber-digital task force specifically and the Justice Department generally.

Since the 2016 election, the Justice Department has focused on criminal prosecutions as a method of resolving foreign election interference. Some of these prosecutions arose from the investigation conducted by Special Counsel Robert Mueller. For example, in February 2018, the Justice Department announced an indictment against 13 individuals and three corporations for running a foreign influence operation out of a troll farm connected to Russian military intelligence. Specifically, the indictment alleged that:

Defendants, posing as U.S. persons and creating false U.S. personas, operated social media pages and groups designed to attract U.S. audiences. These groups and pages, which addressed divisive U.S. political and social issues, falsely claimed to be controlled by U.S. activists when, in fact, they were controlled by Defendants. Defendants also used the stolen identities of real U.S. persons to post on ORGANIZATION-controlled social media accounts. Over time, these social media accounts became Defendants' means to reach significant numbers of

${ }^{66}$ United States Department of Justice, Office of the Deputy Attorney General, Gyber-Digital Task Force, at 12 (2018).

${ }^{67} \mathrm{Id}$. 
Americans for purposes of interfering with the U.S. political system, including the presidential election of 2016 . $^{6}$

Central to these allegations was that the troll farm activity involved Russians posing as Americans.

Many wondered what practical effect the indictment would have. The 13 named individual-defendants are unlikely to be extradited to, or voluntarily visit, the United States, thus keeping them from the long arm of the American judicial system. In a strange twist, however, lawyers representing some of the corporate defendants appeared in federal court in the United States seeking discovery in the case. ${ }^{69}$ This was a brilliant strategic move because the corporations have no U.S.based assets that could be seized as part of a criminal punishment, nor are the directors of the corporations located in the United States. Consequently, the corporations could participate in the case in order to receive discovery - much to the chagrin of American intelligence agencies and the Justice Department - while effectively eliminating their risk of punishment even if they are found guilty. Strategically, the best move to block the discovery requests was to dismiss the charges against the corporate defendants, but the Justice Department was not interested in this option.

What was the value of the indictment if the 13 named individuals could not be extradited to stand trial? The goal, of course, was transparency, because the indictment told a very specific story to the American public about the allegations of Russian interference through the use of social media platforms. Although publicizing these efforts at the macro level might not help individual social media users identify which specific accounts are linked to the troll farm, nonetheless the overall effort helped publicize the nature of the foreign interference - a prosecutorial effort in service of transparency rather than criminal punishment, which is the usual goal of criminal prosecutions.

Of course, the Russian troll farm indictment was an ex-post prosecutionit was announced in 2018, long after the 2016 election and the Russian meddling associated with it. Nothing in 2018 would change what happened in 2016. Moreover, vague predictions that the indictments might deter the Russian government from future interference are wildly implausible. ${ }^{70}$ The value of the

68 United States of America v. Internet Research Agency et al, indictment, at para. 4 (Feb. 16, 2018).

69 Some of these issues are outlined in United States v. Concord Mgmt. E Consulting LLC, 317 F. Supp. 3d 598, 605 (D.D.C. 2018), appeal dismissed, No. 18-3061, 2018 WL 5115521 (D.C. Cir. Sept. 17, 2018).

${ }^{70}$ On the issue of the difficulty of developing a plan that could accomplice deterrence, see Anthony Cuthbertson, Russian Trolls and Fake Newes are Set to Get Even Worse, Warns Former White House Advisor, Newsweek (Feb. 19, 2018) (quoting Virginia Senator Mark Warner as saying that "[w]e've had more 
indictments stem from the publicity they bring to the overall problem, not to the deterrence value they bring to the future. Similarly, it was announced in 2018 that United States intelligence services have a plan which involves identifying - and notifying - Russian operatives involved in election interference activities during the 2018 elections. ${ }^{71}$ Although the details are a bit unclear, the implication is that the U.S. government is privately contacting Russian operatives and communicating to them that their activities and identities have been discovered and they might be subject to economic sanctions, criminal indictment, or other prosecutions. Again, the goal is deterrence and is unlikely to induce compliance from Russian operatives who remain far afield from the coercive machinery of the American legal system. ${ }^{72}$ Even targeted economic sanctions are likely to be ineffective in deterring statesponsored foreign interference, unless the sanctions successfully target the individuals with the decision-making authority to suspend a foreign-influence campaign. ${ }^{73}$

The better option is to release an indictment during the election campaign to publicize the election interference when it is occurring. Although this move, by itself, fails to publicize the particular social media footprint of the indicted individual, it at least gives the public a sense of the overall effort in a way that at least raises the possibility of correction. For example, in July 2018, the Justice Department indicted a Russian national for running "Project Lakhta," a campaign to influence the mid-term elections of November 2018. The indictment alleges that the campaign was coordinated by the Internet Research Agency, the same group named in the February 2018 election interference indictments. According to the indictment, Project Lakhta:

Has a strategic goal, which continues to this day, to sow division and discord in the U.S. political system, including by creating social and political polarization,

than a year to get our act together and address the threat posed by Russia and implement a strategy to deter future attacks... But we still do not have a plan.”).

71 See Ellen Nakashima, Pentagon launches first cyber operation to deter Russian interference in midterm elections, Washington Post (Oct. 23, 2018).

72 The deterrent effect of targeted economic sanctions against the individuals is another matter. This might be effective depending on the circumstances of each case.

${ }^{73}$ President Trump signed an executive order creating a framework for targeted economic sanctions in response to election interference. See Executive Order 13848 (Sept. 12, 2018) (concluding that the "ability of persons located, in whole or in substantial part, outside the United States to interfere in or undermine public confidence in United States elections, including through the unauthorized accessing of election and campaign infrastructure or the covert distribution of propaganda and disinformation, constitutes an unusual and extraordinary threat to the national security and foreign policy of the United States"). The Executive Order also noted that "the proliferation of digital devices and internet-based communications has created significant vulnerabilities and magnified the scope and intensity of the threat of foreign interference." Id. 
undermining faith in democratic institutions, and influencing U.S. elections, including the upcoming 2018 midterm election. The Conspiracy has sought to conduct what it called internally "information warfare against the United States of America" through fictitious U.S. personas on social media platforms and other Internet-based media. ${ }^{74}$

This is precisely the kind of real-world information that the Justice Department should be providing in order to neutralize election interference. Instead of waiting until the election is over to begin criminal investigations, the Justice Department is issuing indictments during the election in order to serve the goals of transparency. This is an appropriate development though it is only the first step.

\section{FOUR OBJEGTIONS}

It remains to respond to four important objections. The United States has a long history of meddling in foreign political systems. ${ }^{75}$ In addition to supporting, planning, or funding coups and assassinations, the CIA has engaged in propaganda efforts to influence foreign politics. In some cases, the influence campaigns have been overt, through Voice of America or other government-funded media outlets, but these overt efforts are unobjectionable because they are transparent. In other cases, however, the U.S. government supported covert and unacknowledged influence campaigns against foreign systems. ${ }^{76}$ These events are often referenced during a larger argument that the Russian election interference is simply of a piece with prior American efforts and therefore neither illegal nor particularly surprising. The charge is that the U.S. government is hypocritical for complaining about foreign influence initiatives given its long history of designing and implementing such programs through the auspices of the CIA or its precursors.

There are several responses to this objection. The first is that not all of the examples of historical American meddling are problematic to the theory presented in this essay. Many of the covert American initiatives targeted illiberal or totalitarian regimes. Those governments arguably did not have an election system that maximized their collective right of self-determination - the latter ground represents the distinctive harm of election interference. Consequently, by meddling in those political systems, the U.S. was not necessarily substituting its political will for the will of the domestic polity, since the latter's government was not an expression of that polity's will in the first instance.

\footnotetext{
${ }^{74}$ United States of America v. Elena Alekseevna Khusyaynova, Indictment, at para. 15 (September 28, 2018).

75 For a discussion, see Ishaan Tharoor, The Long History of the U.S. Interfering with Elections Elsewhere, The Washington Post (Oct. 13th, 2016).

76 See Schmitt, supra note 3.
} 
Of course, not all cases of American interference can be classified as interference in illiberal regimes or undemocratic states. ${ }^{77}$ At least some of those states were democratic ones, and for those, a different response is required. It is odd to say that a given prohibition is irrelevant simply because some actors have violated it before. For example, many states have violated the prohibition against using military force (in violation of article 2 of the UN Charter), but these violations are not evidence that the norm does not exist - indeed, they are simply evidence that the norm has been violated. Furthermore, the fact that a state was once the perpetrator of acts of aggression does not mean that it forfeits its right to complain about acts of aggression against it. It would be odd, for example, to say to Germany that it cannot complain that it is being subjected to unlawful military force simply because Germany perpetrated crimes against peace (or in today's language, aggression) during World War II. Prior bad acts by the victim do not provide immunity for future perpetrators for future bad acts.

A second objection might be raised by international lawyers concerned about the requirements of customary international law. In evaluating whether election interference counts as a violation of the principle of self-determination, one might be tempted to look for state practice, accompanied by opinio juris, that supports the theory. One may ask: have states complained about, or diplomatically protested, election interference as a violation of international law? Moreover, have any states referenced the language of self-determination in making these protests? ${ }^{78}$ If not, the international lawyer might say, there is insufficient evidence of a customary prohibition in this area.

This objection confuses the identification of the legal rule with the application of that legal rule. Customary international law is one source of international legal rules and in identifying a legal rule one must apply the criteria for customary law if no other source of law (such as treaties) is applicable. However, once the legal rule is established as a valid rule of law, one can then apply it in genuinely novel situations. The application of the legal rule need not be supported by customary law as long as the application of the rule is legally sound. In other words, the source of law establishes the legal rule in question but then lawyers must apply the rule in particular circumstances. In this case, custom and treaties establish the validity of the collective right to self-determination. The task of lawyers is to then determine what that right means in practice. This article has been one such exercise, showing that self-determination both protects and allows a people to determine their own

77 See also Dov H. Levin, Sure, the U.S. and Russia often meddle in foreign elections. Does it matter?, Washington Post (September 7, 2016).

78 This issue is discussed in Hollis, supra note 33, at 42 ("Perhaps most importantly, IOs have a longand, some would say, successful - history of interfering with foreign national elections without selfdetermination complaints."). 
political destiny and to use elections - and the membership rules that go along with them - to actualize that right.

The third objection is animated by a concern for First Amendment values. Although the First Amendment probably does not apply extraterritorially to foreign speakers located outside of the country, the First Amendment may protect the right of Americans within the country to receive or consume foreign speech. For example, although a British individual located in Britain does not have a right to free speech that is protected by the U.S. Constitution, an individual living in the United States might have a right to receive communications from the Brit. So, for example, if the government banned the importation of the Financial Times or another British newspaper, the American audience for that foreign speech might argue that their First Amendment rights were infringed by the regulation.

There are two important responses to this objection. The first is that this article is mostly about the international legal framework for responding to election interference. But even if one switches focus to domestic legal obstacles to such regulation, a second response comes to the forefront. The transparency regime articulated in this article would not entail banning the speech; it would simply seek to label that speech as foreign. Nothing in the regime would prevent Americans from consuming foreign speech; it would simply insist that foreign electioneering be labeled as such.

The Fourth and final objection is again animated by First Amendment values. The First Amendment not only protects speech; it also protects anonymous speech in some circumstances. A disclosure regime for foreign electioneering might impinge on the right of Americans to consume anonymous speech. There is a rich tradition in American history of creating and consuming anonymous political speech, including the Federalist Papers which were published in newspapers under "Publius," the collective pen name for Alexander Hamilton, James Madison, and John Jay. Taken to its logical extreme, protection for anonymous speech might preclude regulation of foreign electioneering.

The response to this objection is that it proves too much. Congress has frequently regulated foreign behavior, including foreign speech, without running afoul of the First Amendment. FARA itself, which requires registration of those acting on behalf of a foreign power, prevents those agents from speaking and acting anonymously. The purpose of FARA is not to prevent them from acting, but to require them to do so transparently; to stand up and make clear to the American audience that they are speaking on behalf of a foreign power. It seems no less reasonable to require foreign election speech to similarly be identified as having a foreign origin, especially when it is instigated by a foreign power. The need to protect the integrity of the election process is no less compelling than the need to protect national security; the need to protect the boundaries of the election process 
is internal to the notion of a democratic election and its goal of expressing the polity's views on the nation's future direction, or what I have referred to in this article as the collective right of self-determination.

The anonymous publication of the Federalist Papers was indeed a paradigmatic moment that helped to define American political participation in the marketplace of ideas. But imagine, just for a moment, the results for the birth of our fragile republic if an agent of the British government had anonymously authored an anti-Federalist Papers under the pretense of it being an authentically American document. Surely such a deceptive act, if it took place today, would not only be legitimately regulated by today's FARA but also by additional regulations designed to impose transparency with regard to foreign electioneering.

\section{Conclusion}

With the discussion of recent remedial efforts of the Justice Department in mind, it is important not to obscure the central theoretical move in this article. The argument flowed from a particular conception of self-determination - a norm that has both political salience and legal protection. The concept of self-determination ensures that peoples have a right to select their own destiny, and I have argued here and elsewhere that this right not only entails a right to remedial secession in some circumstances, but also protects that people's right to use democratic institutions to select their political destiny. This was a novel move, because international lawyers have rarely recognized the intuitive connection between the collective right of selfdetermination and the protection of democratic institutions, preferring instead to consistently rely on the concept of sovereignty to frame such discussions despite the fact that sovereignty is ill-suited to this task. ${ }^{79}$ Within our new framework, however, election interference - particularly when it involves outsiders masquerading as insiders - is now revealed to be a fundamental impingement on a people's right of self-determination. The interference interrupts the process by which the insiders express their political preferences and jointly participate in the process of selecting their political destiny. This conceptual framework is far more relevant than the concept of sovereignty, which has unfortunately dominated the discourse on election interference for far too long.

\footnotetext{
79 See, e.g., Zephyr Teachout, Extraterritorial Electioneering and the Globalization of American Elections, 27 Berkeley J. Int'l L. 162, 187 (2009) (concluding that “[o]n the whole, concerns about sovereignty, unlike concerns about self-government, will tend to militate against extraterritorial electioneering"); Jacqueline Van De Velde, The Law of Cyber Interference in Elections, SSRN (May 15th, 2017).
} 